\section{PARAGH GYÖRGY}

egyetemi tanár

Debreceni Egyetem Általános Orvostudományi Kar

Belgyógyászati Intézet

paragh@internal.med.unideb.hu

\section{MUDRÁK JÓZSEF}

egyetemtörténész

Debreceni Egyetem Általános Orvostudományi Kar Konferencia Központ és Orvostörténeti Gyüjtőhely mudrak.jozsef@unideb.hu

\title{
FORNET BÉLA ORVOSPROFESSZOR, A DEBRECENI TUDOMÁNYEGYETEM 1947-48. TANÉVI RECTOR MAGNIFICUSA
}

Dr. Fornet Béla professzor a Debreceni Egyetem iskolateremtö tanára volt, aki közvetlenségével meghitt légkört teremtett nemcsak a klinikáján, hanem a rektori idöszak alatt az Egyetemi Tanácsban is. Török István teológiai dékán megemlékezése szerint "felismerve a társadalmi átalakulás szükségességét rektori tevékenysége alatt a korábbi öröklött formák rovására nagyobb engedményeket tett, mint bármely rektor elödje”. Az elörelátása, közvetlensége eredményeként a betegek bizalmán kivül rektori tevékenysége során mind a diákság, mind a professzorok bizalmát élvezte. Kiemelkedö szakmai munkájának elismeréseként a Debreceni Egyetem Általános Orvostudományi Kara Fornet Béla Emlékérmet alapitott. Ezzel is elösegitve azt, hogy a Kar fejlödése szempontjából meghatározó iskolateremtö professzora a jelen nemzedékének is példát mutatva hozzájáruljon a ma jelentkezö kihivások megfelelö kezeléséhez.

Kulcsszavak: Fornet Béla, belgyógyász, professzor, rektor, diákság, emlékérem

Béla Fornet, Professor of Medicine the Rector Magnificus of the Hungarian Royal István Tisza UNIVERSITY OF DEBRECEN DURING THE ACADEMIC YEAR 1947/48. Professor Dr. Béla Fornet is a schoolcreating professor at the University of Debrecen who, through his directness, created an intimate atmosphere not only in his clinic, but also in the University Council during the rector's term. According to the theological dean István Török, "recognizing the need for social transformation during his rector's activity, he made greater concessions than the predecessor of any rector at the expense of previous inherited forms." As a result of his foresight and directness, in addition to the trust of the patients, he enjoyed the confidence of both the students and the professors during his rector's activities. In recognition of his outstanding professional work, the Faculty of Medicine of the University of Debrecen established the Béla Fornet Commemorative Medal. In this way, the example of a determining school-creating professor in terms of development of the Faculty of Medicine, will help to address the challenges of today by setting an example for the present generation.

Keywords: Béla Fornet, internal medicine, professor, rector, students, commemorative medal

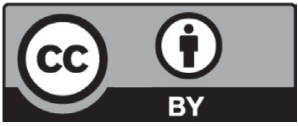

Beérkezett: 2021. 08. 15.

Közlésre elfogadva: 2021. 10. 15.

Copyright GERUNDIUM 


\section{Életút}

Fornet de la Quehardiere Béla Leon Gaszton 1890. március 31-én Párizsban született egy korábban Magyarországra menekült francia hugenotta családból. ${ }^{1}$ Apja, Fornet Elemér a kolozsvári Ferenc József Tudományegyetemen szerzett orvosi diplomát, majd rövid kolozsvári tanársegédi állás után Marienbadban tevékenykedett fürdőorvosként. Anyja, Kovách Júlia a visontai Kovách kisnemesi családból származott. Nevezetes történelmi személyiség volt a nagyapa, Fornet Kornél, aki az 1848-49-es forradalom és szabadságharc honvéd őrnagyaként, majd az amerikai polgárháború ezredeseként tett szert hírnévre.

Fornet Béla középiskolai tanulmányait a budapesti kegyestanítórendi gimnáziumban kezdte, majd a piarista rend tatai, később nyitrai fógimnáziumában folytatta, utóbbi helyen tett 1908-ban érettségit. Édesapja hivatását folytatva az orvosi pályát választotta, és 1908 őszén a Budapesti királyi magyar Tudományegyetem Orvostudományi Karára iratkozott be, ahol 1913-ban szerzett orvosi oklevelet.

Szakmai pályafutását díjtalan gyakornokként 1914-ben a báró Korányi Sándor professzor vezette III. számú Belgyógyászati Klinikán kezdte, majd hamarosan átlépett az I. számú Belgyógyászati Klinika kötelékébe, ahol a klinikaigazgató egyetemi tanár, Bálint Rezső vált igazi mesterévé. Pályáját rövid időre megszakította az I. világháború, 1915-1918 között különböző tábori és tartalék kórházakban teljesített szolgálatot.

A világháború befejeztével visszatért a budapesti I. számú belklinikára, és itt Bálint professzor mellett a ranglétrán lépkedve 1918-tól ismét díjtalan gyakornok, 1920-tól díjas gyakornok (amelyhez 1922-tôl fizetéstelen tanársegédi cím is társult). 1925-ben lett III. tanársegéd, majd 1927-ben I. tanársegéddé lépett elö, 1928-ban adjunktus lett. 1929-ben a budapesti orvosi karon „A belgyógyászat határterületei” tárgykörből magántanárrá is habilitálták.

1929. január 26-án, alig negyvenhét évesen elhunyt a debreceni Tisza IstvánTudományegyetem belgyógyászprofesszora, Csiky József. Az utódlására kiírt pályázatra összesen tizenketten jelentkeztek. Csiky kedvenc tanítványa - akit utódjának szánt Molnár Elek adjunktus, magántanár volt, de őt elhatalmasodó betegsége ekkorra már alkalmatlanná tette a professzori állásra, így visszavonta pályázatát. A kar - hosszas vita után - úgy döntött, hogy I. helyre a másik helybeli embert, Böszörményi-Nagy Géza magántanárt, ${ }^{2}$ volt klinikai tanársegédet, a berettyóújfalui Tisza István Közkór-

${ }^{1}$ Életéről megjelent VÉGH Pál, „Dr. Fornet Béla a Debreceni Tudományegyetem 1947-48. évi Rector Magnificusa”, Debreceni Képes Kalendárium (1948): 101-104. Vö. http://hdl.handle.net/2437/153811. Hozzáférés: 2021. 12. 20. - Életrajzi monográfiája: Kulcsár András, Dr. Fornet Béla élete és munkássága 1890-1966 (Debrecen: DOTE Rektori Hivatala, 1993) - Szintén Fornet Béláról szól a klinika történetének Hankiss János által összeállított első fele: Hankiss János és LeÖveY András, A debreceni I. sz. Belklinika története 1912-2012 (Debrecen: DEOEC Belgyógyászati Intézet, 2013).

${ }^{2}$ Böszörményi-Nagy Géza (ekkoriban még csak Nagy Géza néven) nem lett professzor: 1938-ig a berettyóújfalui, majd 1951-es nyugdíjazásáig a kaposvári kórház igazgató-föorvosa volt. 
ház osztályvezető föorvosát jelöli. A II. helyre Boros József budapesti magántanárt ${ }^{3}$, az I. számú Belgyógyászati Klinika tanársegédét, III. helyre pedig Fornet Bélát helyezték. ${ }^{4}$

A kar, majd az Egyetemi Tanács jelölését figyelembe nem véve, Klebelsberg Kunó miniszter Fornet Bélát terjesztette fel a kormányzónak, így 1930. január 7-én az államfö őt nevezte ki a debreceni orvosi karra a belgyógyászat nyilvános rendes tanárává és egyszersmind a Belgyógyászati Klinika igazgatójává. Fornet a professzori állás mellett megörökölte a Csiky által a Rockefeller-alapból létrehozott Ápoló- és Védőnőképző Intézetet is.

Minthogy a debreceni orvosi kar oktatógárdáját ekkoriban még kevés szakember alkotta, be kellett segíteni a néhány megüresedett tanszék ideiglenes ellátásába annak betöltéséig. Így Kenézy Gyula nyugdíjazása után 1930-1931-ben a Szülészeti Klinika, 1936-1937-ben (Benedek László professzor Budapestre kinevezése) és 1938-1939ben (az új professzor, Somogyi István váratlan halála után) Fornet az Ideg- és Elmeklinika helyettes vezetője is volt. 1938 őszén a budapesti Bőrgyógyászati Klinika élére helyezték át a debreceni professzor Neuber Edét, így a legfontosabb kari bizottság, a Klinikai Bizottság elnöki tisztét tőle Fornet Béla vette át (ez egybe volt kötve az egyetemi kezelésbe átvett városi közkórház igazgató-föorvosi állásával).

Tudományos és közéleti tevékenységének elismeréséül számos tudományos társaság választotta tagjává: 1932-ben a debreceni Tisza István Tudományos Társaság rendes tagja lett, 1942-ben a Wiener Archiv für Innere Medizin szerkesztőbizottságába választották be. A Magyar Belorvosok Egyesületének sok éven át titkára volt, majd 1941-től elnöke. 1944-ben a Debreceni Orvosegyesület, majd 1945-ben az ehelyett alakult Magyar Orvosok Szabad Szakszervezete debreceni csoportja választotta elnökévé.

Fornet Béla professzor 1946. március 12-től 1947. augusztus 31-ig (tehát másfél tanéven át) a debreceni Orvostudományi Kar prodékánja volt Verzár Gyula dékán mellett, ugyanis a karral való összetűzése miatt lemondott Sántha Kálmán dékán nem vállalta a dékáni tisztség lejárta utáni tanévben következő prodékánságot sem.

\section{A rektori év}

Az 1947-48-as tanévre ismét az Orvostudományi Karhoz került a rektorállítás joga, és az ansziennitás elvét figyelembe véve Fornet Béla belgyógyászprofesszort választották meg a Debreceni Tudományegyetem Rector Magnificusává.

${ }^{3}$ Boros József 1938-ban a budapesti II. számú Belgyógyászati Klinika igazgató professzora lett, majd a II. világháború végén Németországba emigrált, és haláláig a Saar-vidéki egyetem belgyógyászprofesszora volt.

${ }^{4}$ Debreceni m. kir. Tisza István-Tudományegyetem Orvostudományi Kara Tanácsülési Jegyzőkönyvek 1929. október 9-i III. rendes ülés, 17. pont. 
Ez az év sem volt könnyű az egyetem életében. A II. világháború utáni demokratikus átalakulás az egyetemet is elérte, és ez fóleg a hallgatóság szervezeteinek az egyetemi döntésekbe való fokozottabb bevonásában csúcsosodott ki. 1948. március 3-án a DESZ (Debreceni EgyetemiSzövetség) a következő beadvánnyal fordultazEgyetemi Tanácshoz:

\begin{abstract}
„Debreceni Tudományegyetem Tanácsának, Debrecen. 1948. február 27-én a Központi Egyetem III. emeleti pihenőjén az egyetem ifjúsága nagygyűlést tartott. Az ifjúság számottevő nagy része és a professzori kar egy része is megjelent ezen a gyülésen. ... A nagygyűlés célja az egyetemi reformok mielőbbi megoldása és az ifjúság szociális helyzetének javítása volt. A Debreceni Egyetemi Szövetség vezetésével a megjelent hallgatóság a fenti célok érdekében a következő határozatokat hozta: - Az ifúság súlyos tanulmányi és szociális problémáinak megoldása és az ifuúság tényleges szerepe és helyzete az egyetemen megköveteli, hogy képviselőiket a kari tanácsokban /ülésekre/ és az Egyetemi Tanácsba bevonják és ott teljes jogú tagokként szerepeljenek. Ennek a határozatnak pozitív megoldásával, vagy e megoldás mellett, ha a szabályzatok úgy rendelkeznek, az ifúság bele szólhasson a professzorok tanszékekre való meghívásába. - Az ifjúság szociális problémáit intéző szervekben /Diákjóléti Bizottság stb./ az ifjúságnak döntő súlya és többsége legyen." ${ }^{5}$
\end{abstract}

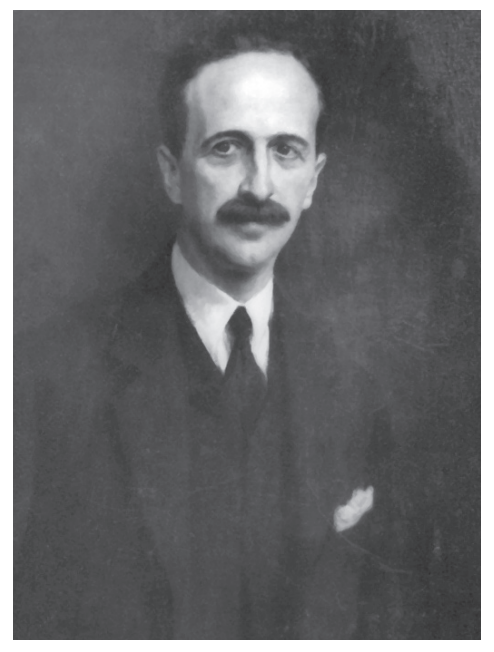

1. kép Fornet Béla arcképe

Glatz Oszkár (1872-1958)

Kossuth-dijas

festömüvész alkotása
Az Egyetemi Tanács az ilyen formában küldött felszólítást elfogadhatatlannak tartotta, viszont nem zárkózott el az elől, hogy „[...] megértéssel fogadna olyan kezdeményezést, amelynek alapján a diákságot legközelebbül érintö kérdésekben alkalma adódnék az ifjúság hivatott képviselöinek óhajaik, vagy panaszaik közvetlen elöadására”.

A kari vezetésben hagyományosan a dualizmus eleje óta csak a kinevezett nyilvános rendes és nyilvános rendkívüli tanárok (azaz a professzorok) és a magántanárok két képviselője, míg az Egyetemi Tanácsban a rektor és prorektor mellett a négy dékán és a négy prodékán foglalt helyet. A kérdés kikerült a négy kar vezetéséhez, akik véleményüket nyilváníthatták a kérdésben. A jogi kar azzal érvelt, „[...] hogy a DESz. ama kivánságát, hogy egyetemünk Tanácsában és a kari üléseken az ifjúság képviseletet nyerjen, közjogi okokból lehetetlen teljesiteni, mivel az 1912:

\footnotetext{
${ }^{5}$ Egyetemi Tanácsülési Jegyzőkönyvek, 1947/48. tanév, VI. rendes ülés, 1948. jan. 30. 190. sz. - Gyakor-
} latilag innen datálható a diákság részvételének kezdete az egyetemi vezetésben. 
XXXVI. t. c. alapján egyetemünk szervezetéröl, tanulmányi és vizsgarendjéröl kiadott szabályzat megváltoztatása csak államföi rendelet útján lehetséges". 6

Az Egyetemi Tanács június 30-i ülésén Pukánszky Béla bölcsészkari dékán összefoglalta a négy kar véleményét, és mivel a kérdés túlhaladta a Tanács hatáskörét, végül abban egyeztek meg, hogy a miniszter elvi döntését kérik. ${ }^{7}$

A tanév során megalkották az új testnevelési és az új egyetemi alkalmazotti fegyelmi szabályzatot is. ${ }^{8}$ Többször is szóba került a gróf Tisza Lajos Kálmán által az egyetemnek felajánlott geszti kastély hasznosítása a diákjóléti bizottság vezetésével, ${ }^{9}$ de hosszas huzavona után a helyi pártszervezet és a megalakuló termelőszövetkezet kisajátította az addigra már kifosztott és lepusztult épületet. ${ }^{10}$

Ugyancsak a tanév során történt a II. Klasszika-filológiai (ógörög) Tanszék megszüntetése, amelynek költségvetési helyét az 1949-ben megalakuló Néprajzi Tanszék foglalta el. Ebben a tanévben is kérte a Bölcsészettudományi Kar vezetése önálló Természettudományi Kar felállítását, amely szintén 1949-ben valósult meg. ${ }^{11}$

A korábbi időszakokban szokásos királygyürüs (sub auspiciis Regis), majd kormányzói gyürűs (sub auspiciis Gubernatoris) kitüntetés doktoravatás új értelmet nyert azáltal, hogy pár évnyi szünet után „sub laurea Almae Matris” néven tért vissza. Lakatos Imre matematikus, Surányi Sándor orvos és Gál Gyula jogász részesültek ebben a kitüntetésben és ünnepélyes keretek között avatták őket doktorrá 1948. április 30-án. Az új idők szelét jelzi, hogy a korábban szokásos aranygyürü helyett - a többi hazai egyetemhez hasonlóan - vasgyürüt adtak a három felavatottnak.

Magas rangú minisztériumi vendégek is ellátogattak Debrecenbe a tanév folyamán: 1947 decemberének végén három napig maga Ortutay Gyula, a vallás- és közoktatásügyi miniszter időzött Debrecenben, utána Tolnay Gábor föosztályvezető 1948. április 29-én, végül Szántó György osztályvezető 1948. június 27-én, illetve 1948. július 2-án látogatott el az egyetemre. Bizonyos, hogy utóbbi kettő érkezése nem protokolláris jellegű volt, hanem a felsőoktatás átalakításával kapcsolatban az egyetemet érintő fon-

${ }^{6}$ ET-Jegyzőkönyv, 1947/48. tanév, XI. rendkívüli ülés, 1948. jún. 30. 256. sz. (Szontagh Vilmos dékán felterjesztése).

${ }^{7}$ ET-Jegyzőkönyv, 1947/48. tanév, XI. rendkívüli ülés, 1948. jún. 30. 256. sz. (Pukánszky Béla dékán összefoglalása).

${ }^{8}$ ET-Jegyzőkönyv, 1947/48. tanév, VII. rendes ülés, 1948. márc. 19. 198., VIII. rendkívüli ülés, 1948. ápr. 12. 204. sz. és XI. rendkívüli ülés, 1948. jún. 30. 257. sz. (A testnevelési szabályzat Went István élettani professzor, az egyetemi alkalmazottakra vonatkozó fegyelmi szabályzat Schultheisz Emil büntetőjogász-professzor munkája volt.)

9 ET-Jegyzőkönyv, 1947/48. tanév, III. rendes ülés, 1947. nov. 17. 53. sz. és VI. rendes ülés, 1948. jan. 30. 137. sz.

${ }^{10}$ A geszti kastély birtokba vételét és a talált állapotokat Vince László rektori titkár is leírta, Bihary Lajos gondnokul kiküldött rektori hivatali altiszt beszámolója alapján: VINCE László (a szöveget gondozta és jegyzetekkel ellátta: Mudrák József), „Egyetemi legendárium - emlékek, töredékek a Debreceni Tudományegyetem történetéből. I. rész." Gerundium - Egyetemtörténeti Közlemények 6, 3-4. sz. (2015) $168-169$.

${ }^{11}$ ET-Jegyzőkönyv, 1947/48. tanév, XII. rendes ülés, 1948. júl. 9. 276. és 266. sz. 
tos kérdésekben is tudakozódhatott az egyetemi vezetés, bár érdemi beleszólásuk már ekkor sem volt.

Török István teológiai kari dékán a következő szavakkal búcsúztatta Fornet Bélát rektori évének végén:

„Magnifice Rector! Az iskolai év végére érve az Egyetemi Tanács nevében megköszönöm Magnificentiádnak rectori éve alatt végzett s mindnyájunk által nagyra értékelt szolgálatait. Nem hozakodhattunk elő olyan apró kari ügyekkel, amit Magnificentiád megértéssel és teljes odaadással fel ne karolt volna. Köszönjük, hogy magas méltóságában is a mindenkor segíteni kész orvosprofesszor maradt. De nekünk különösebb okunk is van a köszönetre: Amikor ez a Tanács megalakult - s most elsősorban az u. n. »kistanács«-ra gondolok, egymást inkább csak hírből ismertük s némi kétely lappangott bennünk a közös munka lehetőségeivel szemben; ez valószínüleg minden új Tanáccsal így van. Hogy ez a kétely mindjárt az első alkalommal tüneményes gyorsasággal szertefoszlott $s$ helyt adott a kölcsönös bizalomnak és megbecsülésnek, abban oroszlán-része van Magnificentiád egyéniségének. Természetes előkelősége és baráti közvetlensége olyan meghitt légkört teremtett, amelyben szinte észrevétlen baráti szálak szövődtek. A jövő évi Rector közülünk való választása már szinte családi esemény számba ment. Ezeket a baráti kapcsolatokat az egyetem jövője szempontjából fontosabbnak tartom, mint azt a pár száz döntést, amit az év folyamán egyetemi ügyekben hoztunk. - Még egy pár szót kell ejtenem a »Fornet-iskolá«-ról. Magnificentiád a társadalmi átalakulás szükségét mindenkor felismerte és elismerte, s bizonyos öröklött formák rovására nagyobb engedményeket tett, mint bármely rector-elődje. Úgy járt azonban a haladás útján, hogy őszinte hagyománytisztelete egy pillanatra sem vált kétségessé előttünk. Ez Magnificentiád kétségtelen sikerének titka; ezzel sikerült mind a diákság, mind a professzorátus osztatlan bizalmát megnyerni és töretlenül megőriznie. Láttuk, Magnificentiád milyen messzemenő áldozatokra képes, ha az emberiesség érdeke megkívánja, de ugyanakkor bizonyosak voltunk abban, hogy szükség esetén tudott volna határozott nem-et is mondani, ha az emberiességet bármiféle túlkapás létében fenyegette volna. Köszönjük ebben a vonatkozásban Magnificentiád a példát. - Érdekes, tanulságos és kedves emlékü tanácsi esztendőre tekinthetünk vissza s amikor Magnificentiádnak a bölcs vezetésért köszönetet mondunk, kívánunk életére és további munkásságára áldást." 12

Fornet Béla rektor válasza ez volt:

„Mélyen tisztelt Dékán Úr! Tekintetes Egyetemi Tanács! - Tisztában vagyok azzal, hogy azokat a szavakat, amelyeket hozzám méltóztatott intézni és amelyek

12 ET-Jegyzőkönyv, 1947/48. tanév, XII. rendes ülés, 1948. júl. 9. 312. sz. 
engem oly sok elismeréssel illettek, sokkal inkább sugalta baráti elfogultság, mint az objektív kritika. - Mégis jóleső érzés tölt el, mert azt merem következtetni, hogy Dékán Úr és a Tanács is méltányolta törekvéseimet és jószándékaimat, különösen pedig a harmonikus együttműködésre irányuló fáradozásaimat. Ezek valóban nem voltak hiábavalók és, hogy ez így volt, azt legelsősorban a Tanács tagjainak kezdettől fogva előlegezett bizalmának és megértő támogatásának köszönhetem. Végtelenül hálás vagyok ezért a bizalomért, amit mindig érezhettem, és aminek birtokában egy-egy nehezebb feladatot is sikerülhetett megoldanunk. - A legutóbbi időkig kevés részem volt az egyetemi administratioban; így kevéssé ismertem a Tanács müködését. Bizonyos az, hogy ezen Tanács mindenegyes tagjában megvolt az egymás megértésére, a haladás szolgálatára való törekvés és mindenegyes tagját áthatotta feladatának tudata és az ifjúság szeretete. Ezért én is mindig hálával és szeretettel fogok erre a tanácsi esztendőre visszatekinteni. - Kérem Dékán Urat, fogadja meleg, baráti szavaiért és a Tanács minden tagja ezért az esztendőért mélységes, hálás köszönetemet."13

\section{Rektorság után}

Az 1940-es évek második felében az egyetem átpolitizálódásával, a balra tolódással próbált lépést tartani. Egy 1960-as önéletrajzában ezt így fogalmazta meg: „Soha azelött politikai pártnak tagja nem voltam, de a munkáspártok egyesülése után Weil Emillel ${ }^{14}$ folytatott eszmecserék hatása alatt 1948-ban, a legkonstruktivabb szándékkal tagja lettem a M. K. P.-nak, amelyböl azonban 1951-ben [...] kizártak."15

A kizárás oka - mint azt az önéletrajzban is megemlíti - egyetlen fiának, Fornet László orvosnak koncepciós pere és kivégzése volt. Fornet László ügye máig tisztázatlan: a vádak szerint belekeveredett egy ellenforradalmi szervezkedésbe; kémkedés és hủtlenség vádjával ítélték halálra és akasztották fel 1949. szeptember 10-én a budapesti Margit-körúti fogházban. ${ }^{16}$ Ekkoriban folyt az országos hírverést kapott Rajk Lászlóper, ennek egyik mellékszálának tekinthető a Fornet László elleni eljárás. Az sem volt igazán jópont akkoriban, hogy édesanyja (Fornet Béla első felesége) báró Zeyk Erzsébet, a neje pedig báró Bánffy Janka volt, tehát arisztokrata családokkal állt rokonságban. Nehéz megérteni, Fornet Béla hogyan tudta folytatni egyetemi, oktató és tudományos munkásságát ilyen tragédia után.

${ }^{13}$ Fornet Béla rektor válasza. (Uo.)

${ }^{14}$ Weil Emil orvos 1945-ig az illegális Kommunista Párt tagja, 1945-től az orvosszakszervezet országos vezetője, a kommunista orvospolitika irányítója volt 1951-ig.

${ }^{15}$ Közli Kulcsár, Dr. Fornet Béla élete és munkássága..., 13.

${ }^{16}$ FeHÉrváry István, Börtönvilág Magyarországon 1945-1956 (Budapest: Magyar Politikai Foglyok Szövetsége, 1990). http://regi.ofm.hu/kiss.szalez/bortonvilag_magyarorszagon_fehervary_istvan_1. html. Hozzáférés: 2021. 12. 20. 
Annyi bizonyos, hogy a rendszer nem akarta őt eltávolítani fia „bűnéért”: 1951 novemberétől a megszűnő egyetemi nyilvános rendes tanári cím helyett tanszékvezető egyetemi tanári titulust kapott, 1952 júliusában az orvostudomány kandidátusa lett, 1964. július 1-jén „Kiváló Orvos” kitüntetést kapott.

Az 1949/50-es egyetemi reform részeként - hasonlóan a budapesti orvostudományi kari klinikákhoz - a vidéki egyetemeken is létrehoztak párhuzamos, második tanszéket és klinikát a két legfontosabb és legátfogóbb orvosi területnek, a belgyógyászatnak és a sebészetnek. Debrecenben 1950. szeptember 22-én nevezték ki Petrányi Gyula budapesti I. sz. belklinikai tanársegédet, magántanárt a belgyógyászat nyilvános rendes tanárává és a felállítandó II. számú Belgyógyászati Klinika igazgatójává. Az új klinika a Városi Kórház belosztályán kezdte meg működését, majd 1951-ben a klinikatelepen az I. számú Belgyógyászati Klinika egyik pavilonjából kialakított önálló épületben folytatta mủködését. ${ }^{17}$

Az I. számú Belgyógyászati Klinika vezető szerepe megmaradt: 128 betegágyon évente 2500-2700 beteget kezeltek. A kialakult speciális szakrendelések 1962-ben már hivatalosan is elismertté váltak. A tudományos munka főleg az allergológia és a gasztroenterológia területére terjedt ki, ezekhez a témakörökhöz kapcsolódott a hepatológia és az endokrinológia. 1945-1966 között a klinika munkatársainak öszszesen mintegy 250 tudományos közleménye jelent meg. Fornet professzor Allergia tankönyve (amelyet korábban Paul Benővel ${ }^{18}$ közösen írt és jelentetett meg 1938-ban) jelentősen átalakítva és modernizálva, most már Kesztyűs Loránd professzorral közösen készítve, nagy sikert ért el, német nyelven is megjelentették. Tantermi előadásaiból összeállított $A$ belgyógyászat alapvonalai című tankönyve hiánypótlónak számított akkoriban. ${ }^{19}$

Klinikáját - még néhány orvosgenerációt felnevelve - 1966. június 21-én bekövetkezett haláláig vezette.

Fornet Béla professzor a Debreceni Tisza István Tudományegyetem Orvosi Karának, majd a Debreceni Orvostudományi Egyetemnek meghatározó, a klinikai betegellátás terén kiemelkedő személyisége volt, akire méltán büszke a Debreceni Egyetem. Csaknem négy évtizeden át oktatta az orvosgenerációkat, irányította a betegellátást és a Belgyógyászaton a kutatómunkát. Előadásai során hangsúlyozta a betegvizsgálat jelentőségét és azt, hogy néha a tipikus tünetek is rejtve maradhatnak. Ennek elkerülése céljából arra tanította az orvostanhallgatókat, hogy a megfigyelés, a tünetelemzés mellett nagyon fontos a betegek panaszainak értékelése és ezeket összhangba kell hozni a változást átélő egyén szubjektív értékelésével. Arra törekedett, hogy feltárja azokat a kóros mechanizmusokat, melyek a tünetek kialakulásában szerepet játszhattak. Ezt a szemléletet tükrözte az általa írt belgyógyászati tankönyv, melyet nemcsak hazánkban,

17100 éves a debreceni orvosképzés I., főszerk. Mátyus László (Debrecen, 2019), 123.

${ }^{18}$ Paul Benő tanársegéd, egyetemi magántanár 1939-ben az USA-ba ment ösztöndíjjal, ahol állást kapott, és nem tért vissza Magyarországra.

19100 éves a debreceni orvosképzés I., 117-118. 
hanem külföldön is használtak. Megtanította azt, hogy a mindennapi gyakorlatban hogyan kell a betegségeket megközelíteni és hogyan kell az orvosnak ezzel kapcsolatban gondolkodni, milyen legyen a differenciáldiagnosztikai megközelítés. Ezen kívül nagy hangsúlyt fektetett arra, hogy hogyan viselkedjen az orvos a beteggel szemben. Ezt tükrözi a Belgyógyászati Klinika tantermén látható felirat is: „Salus aegroti suprema lex esto". A sajátos személyisége, oktatási módszerei lehetővé tették, hogy Debrecenben Fornet-iskola alakuljon ki. Tanítványai, folytatva az ő módszereit, mai napig hatással vannak a belgyógyászat és szélesebb körben a klinikai képzésre. Az oktatói tevékenysége mellett egyetemi, közéleti tevékenységet is vállalt, az 1947/48-as tanévben a Debreceni Tudományegyetem rektori tisztségét töltötte be. Török István a teológiai kari dékán Fornet professzor rektori évének végén tartott búcsúztatója is azt mutatja, hogy a rektori tevékenységét is magas szinten, nagy empátiával, a diákság és a professzori kar nagy megelégedésével végezte.

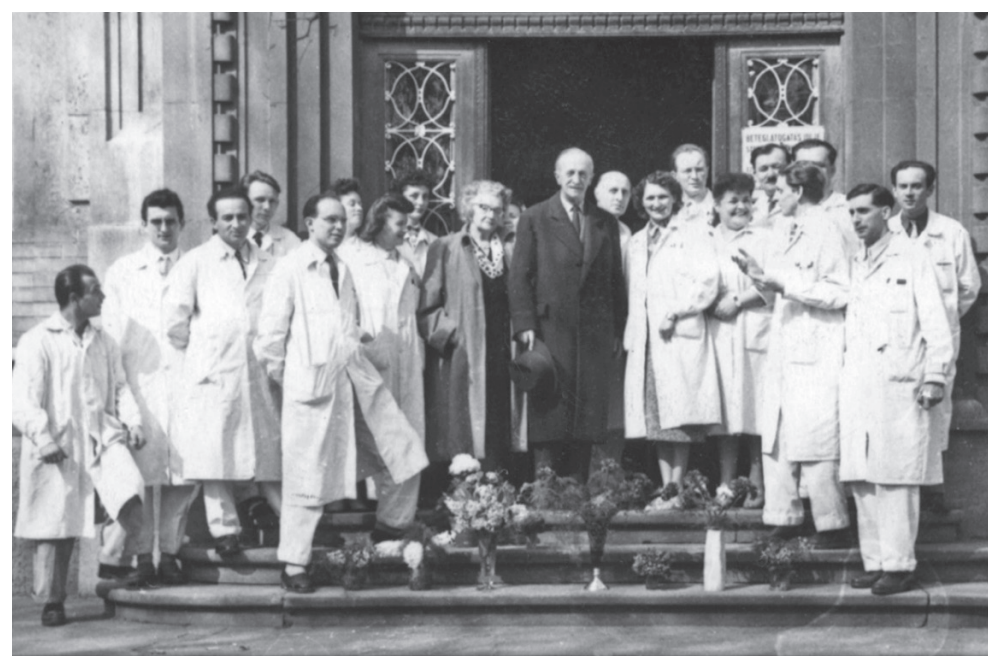

2. kép. Fornet Béla munkatársai körében

Forrás: magángyüjtemény

Pátzay Pál (1896-1979) kétszeres Kossuth-díjas szobrász- és éremművész Fornet Béla halálának 5. évfordulójára emlékérmet készített:
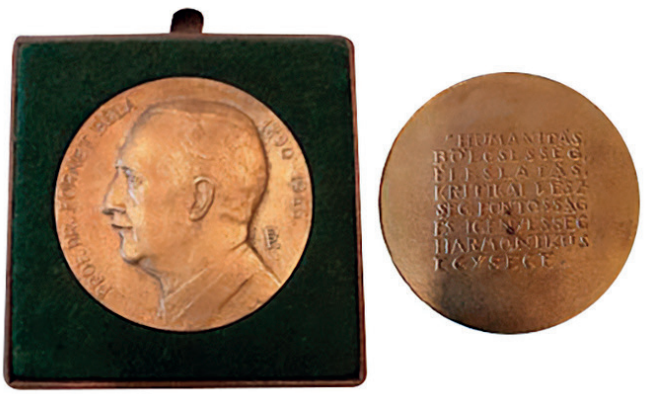
Klinikai, tudományos, oktató- és közéleti munkájának elismeréseként a Debreceni Egyetem Orvostudományi Kara Fornet Béla Emlékérmet alapított. A díjat a belgyógyászati, nem műtéti klinikai orvostudomány területén elért magas szintű eredmények elismeréseként adományozzák minden harmadik évben.

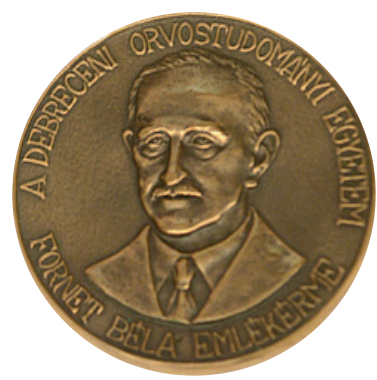

Az emlékérem E. Lakatos Aranka szobrász-és éremmüvész alkotása

A „Méltó Emlék a Múltnak” keretén belül 2012-ben a Debreceni Egyetem Orvosés Egészségtudományi Centruma az I. sz. Belgyógyászati Klinika főbejárata előtt felavatta Fornet Béla Professzor Úr mellszobrát.

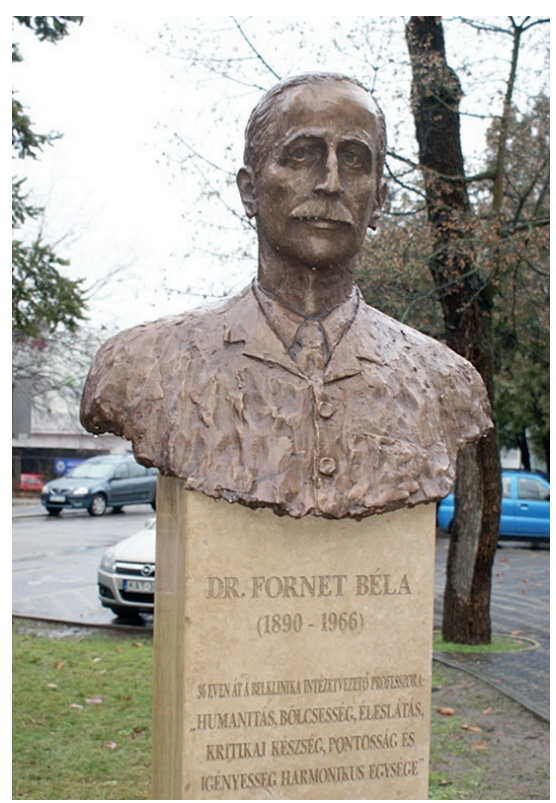

A Fornet Béla mellszobrot

Kövér József szobrászmüvész készitette

A Gerundium szerkesztőbizottsága köszönetet mond dr. Fornet Bélának (Fornet professzor unokája) a közleményhez nyújtott segítségéért. 